J. Dairy Sci. 95:2081-2090

http://dx.doi.org/10.3168/jds.2011-5026

(C) American Dairy Science Association ${ }^{\circledR}, 2012$.

\title{
Use of a corn milling product in diets for dairy cows to alleviate milk fat depression
}

\author{
W. P. Weiss ${ }^{1}$ \\ Department of Animal Sciences, Ohio Agricultural Research and Development Center, The Ohio State University, Wooster 44691
}

\begin{abstract}
Various diet formulation strategies were evaluated to alleviate milk fat depression using a corn milling product (CMP) that contained approximately $28 \%$ crude protein, $34 \%$ neutral detergent fiber (NDF), and $12 \%$ starch (dry basis). The control diet comprised mostly corn silage, alfalfa silage, corn grain, and soybean meal and contained approximately $22 \%$ forage NDF (fNDF), $28 \%$ total NDF, and $33 \%$ starch. Another diet included $25 \%$ CMP that replaced corn grain and soybean meal and contained $27 \%$ starch and $33 \%$ NDF. Two other diets included 25 or $40 \%$ CMP that replaced forage and concentrate and contained 19 and 17\% fNDF, 31 and $32 \%$ total NDF, and 30 and $28 \%$ starch, respectively. Diets were fed to 16 mid-lactation Holstein cows in 4 replicated $4 \times 4$ Latin squares. Milk fat percentage was low for the control diet $(2.9 \%)$ but increased to $3.5 \%$ when cows were fed the diet with $25 \%$ CMP that replaced concentrate. Cows fed diets with 25 or $40 \%$ CMP that replaced forage and concentrate also had low milk fat percentages ( 3.0 and $2.9 \%$, respectively). Intake was lowest for cows fed the control diet. Milk yield was reduced when CMP replaced only concentrate but because of the substantial increase in milk fat, the yield of energy-corrected milk was greater. Calculated energy use (maintenance + milk + body weight change) divided by dry matter intake was similar for the control and for the diet in which CMP replaced only concentrate, but it decreased linearly as increasing amounts of CMP replaced both forage and concentrate. A quadratic equation using the ratio of dietary starch to fNDF was the best predictor of milk fat percentage (ratios $>1.4$ were associated with reduced milk fat). Overall, CMP was effective at alleviating milk fat depression when it replaced corn grain but not when it replaced forage and concentrate.
\end{abstract}

Received October 7, 2011.

Accepted November 19, 2011.

${ }^{1}$ Corresponding author: weiss.6@osu.edu
Key words: milk fat depression, starch, nonforage fiber source, rumen acidosis

\section{INTRODUCTION}

The US corn refining industry used approximately 24.5 million tonnes of corn grain per year between 2004 and 2009 for the production of human foodstuffs such as sweeteners (USDA, 2010). Starch is the primary component used for human foodstuffs; therefore, the resulting corn milling product (CMP) is enriched with fiber and protein. These products can be added to diets simply to reduce diet costs or they can be included for nutritional reasons. In some diets with high starch concentrations, substituting these products for starchy grains could eliminate negative associative effects (Nousiainen et al., 2009) resulting in improved NDF digestibility, increased feed efficiency (FCM/ DMI), and increased milk fat concentration (Allen and Grant, 2000; Boddugari et al., 2001). However, because starch is almost twice as digestible as NDF, on average (Weiss et al., 2009), replacing starch with NDF could reduce the energy concentration of the diet. When CMP replaces a portion of both forage and grain, the concentrations of forage NDF (fNDF) and starch will be reduced. This could result in increased DMI because reducing fNDF in diets can increase DMI, whereas DMI is rather insensitive to inclusion rates of nonforage fiber sources such as CMP (Allen, 2000). If digestibility is reduced because starch is replaced by NDF, the higher DMI may maintain energy intake. However, in studies in which CMP replaced both forage and starchy concentrates, inconsistent effects on DMI and feed efficiency have been reported (Boddugari et al., 2001; Mullins et al., 2010).

The objective of this study was to evaluate the use of a CMP to alleviate milk fat depression caused by a carbohydrate imbalance. We hypothesized that replacing corn grain with CMP would increase milk fat percentage but because NDF is less digestible than starch, feed efficiency would either not be affected or would decrease. We also hypothesized that when CMP replaced forage and corn grain, milk fat depression would be alleviated, 
DMI would increase but feed efficiency would probably decrease because NDF is less digestible than starch.

\section{MATERIALS AND METHODS}

\section{Animals and Experimental Design}

All procedures involving animals were approved by the Ohio State University Agricultural Animal Care Committee. Eight primiparous $(\mathrm{DIM}=93 ; \mathrm{SD}=18)$ and 8 multiparous $(\mathrm{DIM}=98 ; \mathrm{SD}=22)$ Holstein cows were used in a replicated (orthogonal) $4 \times 4$ Latin square experiment with 28 -d periods. Within each parity group, cows were randomly divided into 2 groups of 4 and then each cow was randomly assigned to a treatment sequence within a square. Cows were housed in individual tie stalls, fed once daily for ad libitum intake (orts averaged $6 \%$ of as-fed amounts), and milked twice daily. Cows were weighed on d 2 and 3 of each period and on d 27 and 28 of period 4 , and the 2 consecutiveday BW were averaged to calculate BW change during the period. Body condition was evaluated $(1=$ emaciated, $5=$ obese) on d 2 of each period and on d 28 of period 4 by 2 independent evaluators.

Four diets were formulated to allow for various comparisons of interest. Forage for all diets consisted (DM basis) of $80 \%$ corn silage and $20 \%$ alfalfa silage (Table 1). Diet 1 contained (DM basis) $55 \%$ forage and no CMP (OCMP); diet 2 also contained $55 \%$ forage but included 25\% CMP as a concentrate replacement (25CMP-CR). Diets 3 and 4 contained 25\% CMP (25CMP-FCR) and 40\% CMP (40CMP-FCR), respectively, as a forage and concentrate replacement (Tables 1 and 2). As the concentration of CMP increased from diet 1 to diets 3 and 4, dietary concentrations of fNDF, starch, and NFC decreased linearly and total NDF increased linearly (Table 3). All diets were formulated to meet NRC guidelines (Table 4-3; NRC, 2001) for minimum forage and total NDF and maximum NFC. The concentration of NFC in the 25CMP-FCR and 40CMP-FCR diets was less than the recommended maximum but the 0CMP diet slightly exceeded the NRC (2001) maximum (44.4\% vs. $44.0 \%)$. These 4 treatments allowed us to determine the nutritional value of CMP when replacing mostly corn grain and soybean meal (diets 1 vs. 2) and to quantify the response to increasing concentration of CMP as concentrations of starch and fNDF decreased (diets 1, 3, and 4). The concentrate mixes (excluding the CMP) were pelleted. The CMP was stored in an open-walled shed protected from precipitation. The product was delivered every $3 \mathrm{wk}$ and the experiment was conducted in January through April (average daily temperature $7.4^{\circ} \mathrm{C}, \mathrm{SD}=9.3^{\circ} \mathrm{C}$, minimum and maximum average daily temperatures were -9 and $29^{\circ} \mathrm{C}$ ) and no spoilage was evident.

\section{Sampling and Analyses}

Milk was sampled (a.m. and p.m.) on d 2, 8, 15, and 22 of each period and assayed for milk fat, protein, lactose (B2000 Infrared Analyzer, Bentley Instruments, Chaska, MN), and MUN (Skalar SAN Plus segmented flow analyzer, Skalar Inc., Norcross, GA) by DHI Co-

Table 1. Nutrient composition of the corn milling product and the silages (DM basis) ${ }^{1}$

\begin{tabular}{|c|c|c|c|c|c|c|}
\hline \multirow[b]{2}{*}{ Item } & \multicolumn{2}{|c|}{ Corn milling product } & \multicolumn{2}{|c|}{ Corn silage } & \multicolumn{2}{|c|}{ Alfalfa silage } \\
\hline & Mean & $\mathrm{SD}$ & Mean & $\mathrm{SD}$ & Mean & $\mathrm{SD}$ \\
\hline DM, \% & 71.2 & 0.76 & 34.3 & 1.22 & 56.7 & 2.45 \\
\hline $\mathrm{NE}_{\mathrm{L}},{ }^{2} \mathrm{Mcal} / \mathrm{kg}$ & 1.86 & - & 1.57 & - & 1.31 & - \\
\hline $\mathrm{CP}, \%$ & 27.7 & 0.93 & 6.85 & 0.40 & 19.7 & 0.42 \\
\hline NDF, \% & 34.2 & 0.86 & 39.1 & 1.28 & 43.5 & 0.77 \\
\hline IVNDFD, ${ }^{3} \%$ of NDF & 70.6 & 2.69 & 54.0 & 1.47 & 41.8 & 1.22 \\
\hline Neutral detergent insoluble CP, \% & 3.69 & 0.37 & 0.68 & 0.10 & 2.75 & 0.12 \\
\hline Lignin, \% & 0.56 & 0.11 & 1.65 & 0.16 & 6.20 & 0.34 \\
\hline Starch, \% & 12.8 & 1.50 & 36.6 & 3.04 & 2.82 & 0.44 \\
\hline Long-chain fatty acids, $\%$ & 2.54 & 0.25 & 2.76 & 0.04 & 2.16 & 0.15 \\
\hline Ash, $\%$ & 7.32 & 0.17 & 3.65 & 0.27 & 10.3 & 0.10 \\
\hline $\mathrm{Ca}, \%$ & 0.08 & 0.01 & 0.15 & 0.02 & 2.42 & 0.03 \\
\hline $\mathrm{P}, \%$ & 1.06 & 0.04 & 0.23 & 0.04 & 0.26 & 0.01 \\
\hline $\mathrm{K}, \%$ & 1.75 & 0.01 & 0.85 & 0.07 & 0.96 & 0.02 \\
\hline $\mathrm{Mg}, \%$ & 0.39 & 0.02 & 0.12 & 0.01 & 0.19 & 0.01 \\
\hline \multicolumn{7}{|l|}{ Particle size, $\%$ of as-fed mass } \\
\hline Top screen & - & - & 4.5 & 1.5 & 10.5 & 5.7 \\
\hline Middle screen & - & - & 68.6 & 2.9 & 42.4 & 1.5 \\
\hline Pan & - & - & 26.9 & 1.7 & 47.1 & 4.2 \\
\hline
\end{tabular}

${ }^{1}$ Mean and standard deviation calculated from results of 4 samples (1/period) that were each composited from 4 weekly samples.

${ }^{2} \mathrm{NE}_{\mathrm{L}}$ calculated using NRC (2001) with a constant discount of $8 \%$.

${ }^{3}$ In vitro NDF disappearance during a 30-h incubation. 
Table 2. Ingredient composition of $\operatorname{diets}(\% \text { of DM })^{1}$

\begin{tabular}{lcccc}
\hline Item & 25CMP-CR & 0CMP & 25CMP-FCR & 40CMP-FCR \\
\hline Corn silage & 44.0 & 44.0 & 37.6 & 33.6 \\
Alfalfa silage & 11.0 & 11.0 & 9.4 & 8.4 \\
Corn milling product (CMP) & 25.0 & - & 25.0 & 40.0 \\
Corn grain, ground $_{\text {Soybean meal, 48\% CP }}$ & 9.3 & 20.7 & 17.2 & 13.9 \\
Treated soybean meal $^{2}$ & 4.1 & 16.0 & 5.5 & 0.9 \\
Soybean hulls & -6 & 4.00 & 2.2 & - \\
Fat, animal vegetable blend & 0.70 & 1.00 & - & 0.70 \\
Trace mineral salt $_{\text {Limestone }}$ & 0.55 & 0.70 & 0.70 & 0.55 \\
Dicalcium phosphate $_{\text {Magnesium sulfate }}$ & - & 0.55 & 1.59 & - \\
Trace nutrient premix $^{3}$ & - & 0.39 & - & - \\
\hline
\end{tabular}

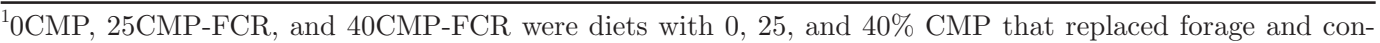
centrate; $25 \mathrm{CMP}-\mathrm{CR}$ had $25 \% \mathrm{CMP}$ that replaced concentrate.

${ }^{2}$ Nonenzymatically browned soybean meal (SurePro, Land O' Lakes Inc., St. Paul, MN).

${ }^{3}$ Contained $170 \mathrm{mg}$ of biotin, $810 \mathrm{kIU}$ of vitamin A, $255 \mathrm{kIU}$ of vitamin D, 4,840 IU of vitamin E, $40 \mathrm{mg}$ of selenium (from sodium selenate), 2,120 $\mathrm{mg}$ of $\mathrm{Cu}$ (from copper sulfate), and 3,700 $\mathrm{mg}$ of $\mathrm{Zn}$ (from zinc sulfate) per $\mathrm{kg}$ of premix.

operative Inc. (Columbus, OH). A subsample of milk (a.m. and p.m.) taken on d 28 of each period was composited by cow into a single sample and assayed for fatty acid profile using a 2-step procedure for methylation (Jenkins, 2000) with separation by gas-liquid chromatography using a CP-SIL88 capillary column $(100 \mathrm{~m}$ $\times 0.25 \mathrm{~mm} \times 0.2-\mu \mathrm{m}$ film thickness; Varian Inc., Palo Alto, CA). A blood sample $(5 \mathrm{~mL})$ was taken from the tail vein on d 2 and 24 of each period approximately $6 \mathrm{~h}$ after feeding. The blood was allowed to clot and then serum was removed after centrifugation $(10,000$ $\times g$ for 15 min at $\left.4^{\circ} \mathrm{C}\right)$ and stored frozen $\left(-20^{\circ} \mathrm{C}\right)$ until analysis for haptoglobin and amyloid A (cat. nos. TP801 and TP 802, respectively; Tridelta Development Ltd., Boonton, NJ). Because of cost and the lack of treatment and time effects on haptoglobin, amyloid A was assayed only on d 2 samples.

Silages were sampled weekly and analyzed for DM $\left(100^{\circ} \mathrm{C}\right.$ oven, overnight) to adjust as-fed amounts to account for moisture changes. A subsample of each silage

Table 3. Nutrient composition of diets (DM basis) ${ }^{1}$

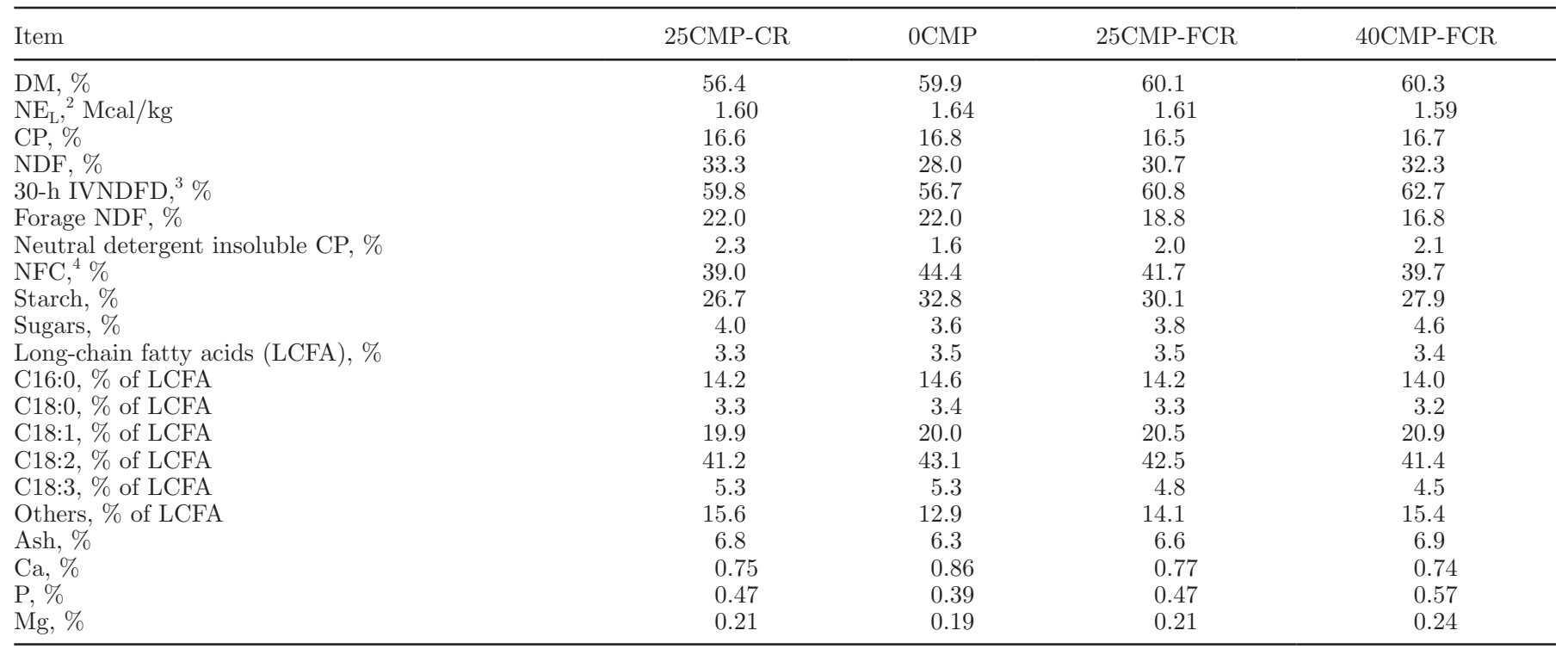

${ }^{1} 0 \mathrm{CMP}, 25 \mathrm{CMP}-\mathrm{FCR}$, and 40CMP-FCR had 0, 25, and 40\% corn milling product (CMP) replacing forage and concentrate; 25CMP-CR had $25 \%$ CMP replacing concentrate.

${ }^{2}$ Calculated using NRC (2001) and mean DMI for each treatment.

${ }^{3}$ In vitro NDF digestibility after $30 \mathrm{~h}$.

${ }^{4} 100-\mathrm{NDF}-\mathrm{CP}-$ ash - fat, where fat = long-chain fatty acids + 1 (NRC, 2001). 
was retained in the freezer and composited by period. Samples of the concentrate mixes and CMP (samples stored in the freezer) were taken weekly and composited by period. Composited samples were ground (silage and CMP samples were lyophilized first) through a 1-mm screen (Wiley mill, Arthur H. Thomas, Philadelphia, $\mathrm{PA})$ and assayed for $\mathrm{DM}\left(100^{\circ} \mathrm{C}\right.$ oven for $\left.24 \mathrm{~h}\right)$, NDF $\left(\right.$ Ankom ${ }^{200}$ Fiber Analyzer, Ankom Technology, Fairport, NY) with sodium sulfite and amylase (A3306, Sigma Diagnostics, St. Louis, MO), CP (Kjeldahl N $\times 6.25$ ), ash (AOAC, 2000), starch (Weiss and Wyatt, 2000), and long-chain fatty acids (Weiss and Wyatt, 2003). The NDF residue was assayed for N (neutral detergent insoluble CP). Samples of silages, CMP, and TMR (constructed from ground feed samples) were assayed for 30-h in vitro NDF digestibility (Cumberland Valley Analytical Services, Hagerstown, MD; Goering and Van Soest, 1970). The constructed TMR samples were assayed for sugars (Dubois et al., 1956). Orts were sampled from each cow on d 9 and 23 of each period and assayed for $\mathrm{DM}\left(100^{\circ} \mathrm{C}\right.$ oven, overnight) to calculate daily DMI.

\section{Statistical Analyses}

For production measurements, data collected the last 2 wk of each period were averaged within cow and analyzed statistically using PROC MIXED (SAS Institute, 2004). The model included parity (fixed, $1 \mathrm{df}$ ), square within parity (random, $2 \mathrm{df}$ ), cow within square (random, $12 \mathrm{df}$ ), period (random, $3 \mathrm{df}$ ), treatment (fixed, 3 df), treatment $\times$ parity (fixed, $3 \mathrm{df}$ ), and error (39 df). To evaluate adaptation to diets, milk fat and protein percentages and yields, DMI, and milk yield data were averaged by week within period ( 4 wk per period) and then week (fixed, repeated measure, $3 \mathrm{df}$ ), week $\times$ parity (fixed, $3 \mathrm{df}$ ), and week by treatment (fixed, $9 \mathrm{df}$ ) were included in the model described previously. If a treatment $\times$ week interaction was found $(P<0.05)$, it was evaluated using the SLICE option. The same model was used to evaluate acute phase proteins except that sampling time (2 per period) replaced the week term. For all statistical analyses, the treatment degrees of freedom were partitioned into 3 contrasts: (1) effect of replacing concentrate with CMP (0CMP vs. 25CMP-CR), and (2) linear and (3) quadratic effects of increasing CMP (contrasts were based on unequal spacing of inclusion rates) while decreasing forage and concentrate (0CMP, 25CMP-FCR, and 40CMP-FCR). Relationships between milk fat and dietary concentrations and ratios of carbohydrates were evaluated using PROC MIXED. The model included cow and period as random effects and a specific dietary concentration or ratio as a continuous variable but not treatment.

\section{RESULTS AND DISCUSSION}

No interactions between parity and treatment were observed for any measure $(P>0.25)$; therefore, parity will not be discussed.

\section{Intake}

Replacement of concentrate or replacement of forage and concentrate with CMP resulted in greater DMI. Dry matter intake increased linearly as CMP replaced forage and concentrate $(P<0.01)$, and DMI was greater $(P<0.01)$ for cows fed 25CMP-CR than for cows fed 0CMP. Mullins et al. (2010) also reported a linear increase in DMI as CMP replaced forage and concentrate. In both our study and theirs, dietary NDF concentrations did not change markedly among diets. Conversely, Boddugari et al. (2001) reported lower DMI when cows were fed a diet with CMP that replaced a mix of forage and concentrate, but in that study dietary NDF increased from 27.5 to $35 \%$ when CMP was added. Two different mechanisms of intake regulation may be involved in the responses we observed. When CMP replaced corn grain and soybean meal, the concentration of fNDF did not change but the concentration of starch decreased from about 33 to $27 \%$. The fill potential of the 0CMP and 25CMP-CR diets was probably similar because of equal fNDF concentrations; therefore, DMI may have been regulated by flow of oxidative fuel to the liver (Allen et al., 2009). The 25CMP-CR diet, because of lower starch concentrations, may have produced less ruminal propionate per kilogram of DMI than did the 0CMP diet; therefore, greater DMI was needed to reach the propionate set point of the liver. Dry matter intake increased linearly $(P<0.05)$ as the inclusion of CMP increased, coinciding with linear decreases in dietary concentrations of fNDF and starch (Table 3). Therefore, as CMP increased in the diets, both the fill potential (i.e., lower concentrations of fNDF) and production of propionate (i.e., greater concentration of starch) likely decreased, both of which could allow increased DMI.

\section{Milk Yield and Composition}

Yields of milk and ECM did not change, and milk composition and yields of milk components were either not affected or only slightly altered as increasing amounts of CMP replaced both forage and concentrate (Table 4). The concentrations of milk fat and protein responded quadratically to increasing CMP (maximal with 25CMP-FCR) but over the 3 treatments, milk fat and protein percentages varied by less than 0.1 units. Protein yield did not vary across those 3 treatments but fat yield showed a quadratic response 
similar to that observed for milk fat percentage. The response was quite small; milk fat yield for cows fed the 25CMP-FCR diet averaged only $60 \mathrm{~g} / \mathrm{d}$ more than for the other 2 treatments. When CMP replaced only concentrate, milk $(P<0.06)$ and lactose $(P<0.07)$ yields decreased; however, yield of ECM increased $(P$ $<0.05)$ because of substantial increases $(P<0.01)$ in milk fat percentage and yield. The $25 \mathrm{CMP}-\mathrm{CR}$ diet had the lowest concentration of starch, and cows fed that diet consumed the least amount of starch (Table 5). This might have resulted in less ruminal propionate production, which reduced glucose synthesis, resulting in less lactose production, which can reduce milk yield. Knowlton et al. (1998) found that increasing ruminal starch (via infusion) increased the yield of lactose but rather than increasing glucose synthesis, glucose oxidation was reduced. However, the net result would be increased glucose availability to the mammary gland. The decrease in lactose yield when CMP replaced corn and soybean meal was quite modest $(2.5 \%)$, and others (Jurjanz et al., 1998; Gencoglu et al., 2010; Ranathunga et al., 2010) have reported little or no effect on lactose yield when nonforage fiber sources replaced corn.

By far, fat was the milk component most affected by treatment (Table 4). When CMP replaced concentrate, milk fat concentration and yield increased markedly $(P$ $<0.01)$. The 2 diets were equal in fNDF, suggesting that chewing and salivary buffer production was similar but the higher starch in the 0CMP diet likely produced more acids, resulting in lower ruminal $\mathrm{pH}$ and milk fat depression. When the concentration of fNDF is held constant and NDF replaces starch, milk fat yield and concentration often increase (Voelker and Allen, 2003; Beckman and Weiss, 2005).

The quadratic response in milk fat (Table 4) to linear changes in dietary components (Table 3) as CMP increased suggested that interactions among the various components were involved. To evaluate how change in nutrients affected milk fat, a statistical analysis was used that included concentrations or ratios of dietary carbohydrates as a continuous variable. If terms were significant $(P<0.05)$, the Bayesian information criterion (BIC, Table 6) was used to evaluate goodness of fit (lower numbers indicate better fit). Increasing dietary concentrations of starch and NFC had linear negative effects on milk fat percentage, and increasing concentrations of NDF and fNDF had linear positive effects on milk fat (Table 6). The quadratic term for those fractions was either not significant (starch and fNDF) or increased the BIC (NDF, NFC; data not shown). To account for the antagonistic relationship between increased ruminal acid production (i.e., NFC and starch) and buffering potential (i.e., NDF and fNDF), ratios of those fractions were examined. Ratios of NFC to NDF or starch to NDF were somewhat better linear predictors of milk fat than were the single nutrients (Table

Table 4. Effect of replacing only concentrate or forage and concentrate with a corn milling product (CMP) on production measures of lactating cows

\begin{tabular}{|c|c|c|c|c|c|c|c|c|}
\hline Item & \multicolumn{4}{|c|}{ Dietary treatment ${ }^{1}$} & $\mathrm{SE}$ & \multicolumn{3}{|c|}{ Contrast $^{2}$} \\
\hline DMI, $\mathrm{kg} / \mathrm{d}$ & 24.1 & 22.8 & 24.4 & 25.1 & 0.48 & 0.01 & 0.01 & 0.7 \\
\hline ECM, kg/d & 40.0 & 37.9 & 38.8 & 37.5 & 1.08 & 0.02 & 0.8 & 0.12 \\
\hline Milk $\mathrm{NE}_{\mathrm{L}},{ }^{3} \mathrm{Mcal} / \mathrm{d}$ & 27.2 & 25.5 & 26.4 & 25.4 & 0.8 & 0.02 & 0.9 & 0.13 \\
\hline Milk/DMI & 1.68 & 1.84 & 1.70 & 1.64 & 0.05 & 0.01 & 0.01 & 0.7 \\
\hline Milk fat, $\mathrm{kg} / \mathrm{d}$ & 1.40 & 1.18 & 1.24 & 1.17 & 0.05 & 0.01 & 0.9 & 0.05 \\
\hline Milk protein, \% & 2.98 & 2.99 & 3.07 & 3.01 & 0.06 & 0.6 & 0.5 & 0.09 \\
\hline Milk protein, $\mathrm{kg} / \mathrm{d}$ & 1.20 & 1.24 & 1.27 & 1.24 & 0.03 & 0.10 & 0.9 & 0.19 \\
\hline Lactose, $\%$ & 4.78 & 4.77 & 4.79 & 4.80 & 0.05 & 0.8 & 0.5 & 0.9 \\
\hline Lactose, $\mathrm{kg} / \mathrm{d}$ & 1.93 & 1.98 & 1.99 & 1.98 & 0.06 & 0.02 & 0.9 & 0.12 \\
\hline MUN, mg/dL & 14.8 & 15.0 & 14.9 & 15.3 & 0.48 & 0.7 & 0.7 & 0.6 \\
\hline
\end{tabular}


Table 5. Effect of replacing only concentrate or both forage and concentrate with a corn milling product (CMP) on intake of carbohydrates and carbohydrate ratios

\begin{tabular}{|c|c|c|c|c|c|c|c|c|}
\hline \multirow[b]{2}{*}{ Item } & \multicolumn{4}{|c|}{ Dietary treatment ${ }^{1}$} & \multirow[b]{2}{*}{$\mathrm{SE}$} & \multicolumn{3}{|c|}{ Contrast $^{2}$} \\
\hline & 25CMP-CR & 0CMP & 25CMP-FCR & 40CMP-FCR & & $\mathrm{C}$ & $\mathrm{L}$ & $\mathrm{Q}$ \\
\hline Forage NDF, kg/d & 5.3 & 5.0 & 4.6 & 4.2 & 0.11 & 0.01 & 0.01 & 0.4 \\
\hline $\mathrm{NFC}, \mathrm{kg} / \mathrm{d}$ & 9.4 & 10.1 & 10.1 & 10.0 & 0.20 & 0.01 & 0.6 & 0.4 \\
\hline Starch, $\mathrm{kg} / \mathrm{d}$ & 6.4 & 7.5 & 7.3 & 7.0 & 0.16 & 0.01 & 0.01 & 0.35 \\
\hline Starch:NDF & 0.80 & 1.17 & 0.98 & 0.87 & 0.13 & 0.01 & 0.01 & 0.8 \\
\hline Starch:forage NDF & 1.21 & 1.49 & 1.60 & 1.67 & 0.020 & 0.01 & 0.01 & 0.9 \\
\hline
\end{tabular}

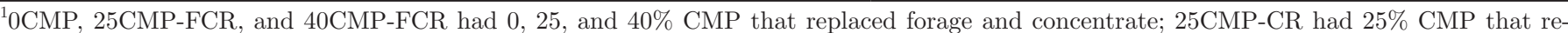
placed concentrate.

${ }^{2}$ Linear (L) and quadratic (Q) effects of increasing CMP (0CMP, 25CMP-FCR, and 40CMP-FCR) and effect of replacing concentrate (C) with CMP (25CMP-CR vs. 0CMP).

6 ). The quadratic terms for those ratios were significant and resulted in better fit than the linear models. The 2 equations that had substantially lower BIC than the other equations were the quadratic equations that included either starch:fNDF or NFC:fNDF ratio. Based on the quadratic equations (Table 6), milk fat concentration decreased substantially as the ratio of starch to fNDF decreased to $<1.4$, and was generally low and constant at higher ratios (Figure 1). The relationship between milk fat and NFC:fNDF was similar, with a breakpoint at approximately 2 (data not shown). This experiment was not designed to evaluate carbohydrate ratios; therefore, ratios and treatments are confounded somewhat (as indicated by the treatment clustering in Figure 1). Thus, factors other than carbohydrate ratios that were specific to treatments could have contributed to the observed milk fat depression. Furthermore, a single optimal value for those ratios probably does not exist because numerous other factors such as particle size, concentration of unsaturated fat, and rumen degradability of the starch can affect milk fat.

\section{Milk Fatty Acids}

The concentrations of most milk FA differed between cows fed the 25CMP-CR and 0CMP diets (Table 7). In general, cows fed the 0CMP diet had lesser concentrations (percentage of total FA) of short-chain fatty acids ( $<14 \mathrm{C}), \mathrm{C} 16: 0$, and C18:0, and greater concentrations of most MUFA (especially trans-10 C18:1), C18:2, C18:3, and cis-10,trans-12 conjugated linoleic acid (CLA) than cows fed the 25CMP-CR diet. The observed changes in short-chain fatty acids, MUFA, and cis-10,trans-12 CLA suggest that cows fed 0CMP had ruminal acidosis (Colman et al., 2010). The higher C18:2 in milk for the 0CMP diet probably reflected the higher concentration of 18:2 in the diet. Few milk FA were affected when CMP replaced both forage and con-

Table 6. Relationships (all $P<0.01$ except where noted) between milk fat percentage and dietary concentrations and ratios of concentrations (\% of DM) of carbohydrate fractions

\begin{tabular}{|c|c|c|c|c|}
\hline $\begin{array}{l}\text { Independent } \\
\text { variable }^{1}\end{array}$ & $\begin{array}{c}\text { Linear } \\
\text { coefficient (SE) }\end{array}$ & $\begin{array}{c}\text { Quadratic } \\
\text { coefficient (SE) }\end{array}$ & $\begin{array}{l}\text { Intercept } \\
\quad(\mathrm{SE})\end{array}$ & $\mathrm{BIC}^{2}$ \\
\hline Starch & $-0.070(0.018)$ & - & $5.12(0.54)$ & 88.1 \\
\hline NFC & $-0.73(0.21)$ & - & $6.09(0.88)$ & 90.3 \\
\hline NDF & $0.078(0.021)$ & - & $0.63^{\mathrm{NS}}(0.67)$ & 88.9 \\
\hline Forage NDF (fNDF) & $0.061(0.020)$ & - & $1.18(0.42)$ & 92.6 \\
\hline Starch:NDF & $-1.29(0.20)$ & - & $4.99(0.32)$ & 83.5 \\
\hline Starch:NDF & $-11.71(4.63)$ & $5.33(2.32)$ & $9.28(2.26)$ & 75.1 \\
\hline Starch:fNDF & $-1.14(0.31)$ & - & $4.15(0.31)$ & 70.7 \\
\hline Starch:fNDF & $-12.74(3.27)$ & $3.98(1.13)$ & $13.08(2.32)$ & 57.4 \\
\hline NFC:NDF & $-0.95(0.28)$ & - & $4.33(0.38)$ & 85.3 \\
\hline NFC:NDF & $-14.22(5.50)$ & $4.79(1.99)$ & $13.39(3.77)$ & 76.7 \\
\hline NFC:fNDF & $-0.88(0.17)$ & - & $4.91(0.38)$ & 75.8 \\
\hline NFC:fNDF & $-12.10(3.01)$ & $2.70(0.72)$ & $16.42(3.11)$ & 62.2 \\
\hline
\end{tabular}

${ }^{1}$ Independent variables were dietary concentrations (\% of DM) or ratios of concentrations.

${ }^{2}$ Bayesian information criterion (a lower number indicates a better statistical fit).

${ }^{\text {NS }} P>0.35$; not significant. 


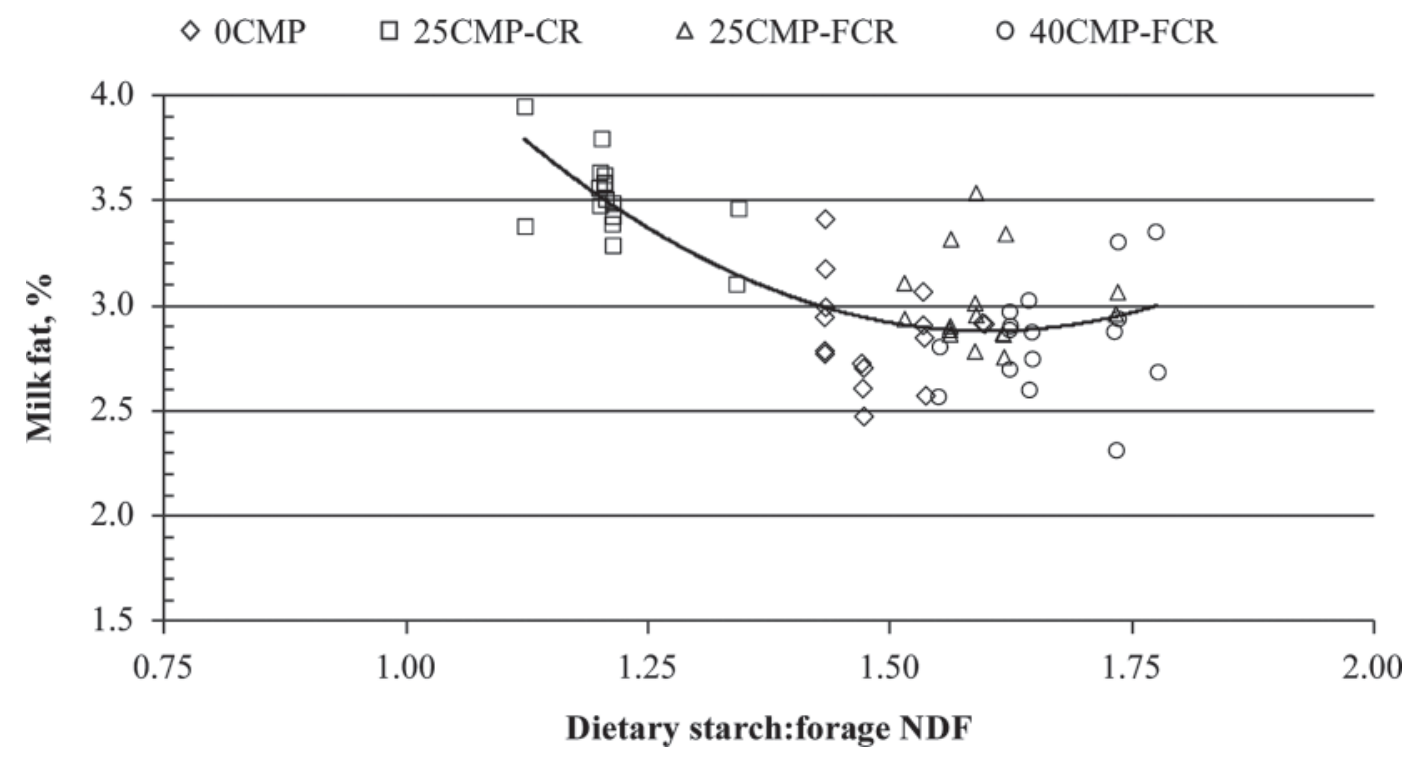

Figure 1. Relationship between ratio of starch and forage NDF (both as \% of diet DM) and milk fat of cows fed diets with various amounts of a corn milling product (CMP). The 0CMP, 25CMP-FCR, and 40CMP-FCR had 0, 25 and 40\% CMP that replaced forage and concentrate and 25CMP-CR had 25\% CMP that replaced concentrate. The line was fit using all data points.

centrate, and the effects were small compared with differences when CMP replaced only concentrate. Several trans 18:1 fatty acids (trans-6, 8, 9, and 10) and cis10,trans-12 CLA had a significant quadratic response to increasing CMP. The intermediate concentration of CMP produced the lowest concentrations of those FA, and the same treatment resulted in the highest milk fat percentage of the 3 diets used in this comparison (Tables 4 and 7). The concentrations of 18:2 and 18:3 decreased linearly with increasing CMP but this probably reflects differences in dietary FA. The concentrations of 16:1 and 18:1 trans-11 and trans-12 decreased linearly with increasing CMP but the changes were quantitatively small. Overall, milk FA profiles are suggestive of various degrees of ruminal acidosis for 3 of the 4 diets.

\section{Acute Phase Proteins}

Subacute rumen acidosis is thought to induce systemic inflammation, resulting in elevated serum concentrations of acute phase proteins, and the degree of milk fat depression caused by subacute ruminal acidosis has been correlated with changes in concentrations of these proteins (Khafipour et al., 2009; Zebeli and Ametaj, 2009). We measured haptoglobin and amyloid A on d 2 (30 h after an abrupt change in diets) and on d 28 of each period. Haptoglobin concentrations were not affected by day, treatment, or treatment by day interaction $(P>0.7$; Table 8$)$. The lack of a day effect suggests that abruptly changing diets did not cause a release of acute phase proteins. A weak quadratic effect of increasing CMP was observed $(P<0.12)$. Although the relationship was weak, it followed the same pattern as the quadratic effect observed for milk fat concentration. However, no difference $(P>0.4)$ in haptoglobin was observed between the treatments with the greatest difference in milk fat (25CMP-CR vs. 0CMP; Table 8).

\section{Efficiency}

Feed efficiency, calculated as ECM/DMI, decreased linearly $(P<0.05)$ as the concentration of CMP increased, but was not affected when CMP replaced only concentrate (Table 4). Dietary $\mathrm{NE}_{\mathrm{L}}$ concentration was estimated by dividing calculated (NRC, 2001) total $\mathrm{NE}_{\mathrm{L}}$ use (maintenance, milk $\mathrm{NE}_{\mathrm{L}}$, and $\mathrm{BW}$ change) by DMI. Dietary $\mathrm{NE}_{\mathrm{L}}$ concentration was also estimated using the NRC (2001) model. With the model, the 0CMP diet had the highest concentration of $\mathrm{NE}_{\mathrm{L}}$ and it decreased slightly (maximum change was about $3 \%$ ) as $\mathrm{CMP}$ was added to the diets (Table 3). However, $\mathrm{NE}_{\mathrm{L}}$ calculated from production measures differed much more among diets (Table 4). As increasing amounts of CMP replaced forage, corn, and soybean meal, the calculated dietary $\mathrm{NE}_{\mathrm{L}}$ decreased linearly $(P<0.01)$. The diet with $40 \%$ CMP had about $9.5 \%$ less $\mathrm{NE}_{\mathrm{L}} / \mathrm{kg}$ than did the control diet. When CMP replaced only concentrate, calculated dietary $\mathrm{NE}_{\mathrm{L}}$ was the same as for the control diet (Table 4). These responses appear inconsistent; in one instance, $\mathrm{CMP}$ had an $\mathrm{NE}_{\mathrm{L}}$ value equal to that of a mix of corn grain and soybean meal but, in another instance, it had less energy than a mix- 
Table 7. Effect of replacing only concentrate or both forage and concentrate with a corn milling product (CMP) on milk FA (\% of total FA)

\begin{tabular}{|c|c|c|c|c|c|c|c|c|}
\hline $\mathrm{FA}^{1}$ & \multicolumn{4}{|c|}{ Dietary treatment ${ }^{2}$} & $\mathrm{SE}$ & \multicolumn{3}{|c|}{ Contrast $^{3}$} \\
\hline $4: 0$ & 3.55 & 3.06 & 3.26 & 3.25 & 0.17 & 0.01 & 0.26 & 0.6 \\
\hline $8: 0$ & 1.20 & 1.01 & 1.04 & 1.03 & 0.07 & 0.01 & 0.7 & 0.8 \\
\hline 10:0 & 2.76 & 2.41 & 2.49 & 2.43 & 0.17 & 0.02 & 0.8 & 0.6 \\
\hline $12: 0$ & 3.20 & 3.34 & 3.26 & 3.18 & 0.18 & 0.30 & 0.9 & 0.5 \\
\hline $15: 0$ & 1.16 & 1.38 & 1.34 & 1.24 & 0.07 & 0.02 & 0.14 & 0.5 \\
\hline $16: 0$ & 32.7 & 29.9 & 31.3 & 30.4 & 0.78 & 0.01 & 0.09 & 0.01 \\
\hline $16: 1$ & 2.24 & 2.78 & 2.46 & 2.50 & 0.19 & 0.01 & 0.03 & 0.19 \\
\hline $18: 0$ & 9.02 & 8.29 & 8.64 & 8.77 & 0.41 & 0.01 & 0.07 & 0.8 \\
\hline $18: 1$ trans $-6,8$ & 0.39 & 0.65 & 0.56 & 0.64 & 0.04 & 0.01 & 0.5 & 0.01 \\
\hline 18:1 trans -9 & 0.27 & 0.44 & 0.37 & 0.40 & 0.03 & 0.01 & 0.12 & 0.06 \\
\hline 18:1 trans -10 & 1.21 & 3.05 & 2.40 & 2.84 & 0.27 & 0.01 & 0.25 & 0.03 \\
\hline $18: 3$ & 0.39 & 0.47 & 0.39 & 0.35 & 0.02 & 0.01 & 0.01 & 0.5 \\
\hline CLA, cis-9,trans-11 & 0.69 & 0.71 & 0.63 & 0.53 & 0.04 & 0.7 & 0.01 & 0.8 \\
\hline CLA, cis-10,trans-12 & 0.000 & 0.059 & 0.026 & 0.047 & 0.01 & 0.01 & 0.26 & 0.04 \\
\hline
\end{tabular}

${ }^{1}$ Number of carbons:number of double bonds.

${ }^{2} 0 \mathrm{CMP}$, 25CMP-FCR, and 40CMP-FCR had 0, 25, and 40\% CMP that replaced forage and concentrate; $25 \mathrm{CMP}-\mathrm{CR}$ had $25 \% \mathrm{CMP}$ that replaced concentrate.

${ }^{3}$ Linear (L) and quadratic (Q) effects of increasing CMP (0CMP, 25CMP-FCR, and 40CMP-FCR) and effect of replacing concentrate (C) with CMP (25CMP-CR vs. 0CMP).

ture of forage, corn grain, and soybean meal. When CMP replaced corn and soybean meal, milk fat percentage increased, suggesting that acidosis may have been alleviated. Although starch is almost always much more digestible than NDF (e.g., Weiss et al., 2009) and the 25CMP-CR diet had approximately 5.5 percentage units more NDF than the 0CMP diet (with a concomitant decrease in starch), the high starch concentration of the 0CMP probably caused negative associative effects. When CMP replaced forage and concentrate, all diets resulted in low milk fat percentages; therefore, the addition of CMP in those diets likely did not reduce negative associative effects. However, the digestibility of diets likely decreased as CMP increased because NDF is usually less digestible than starch and because of the negative effect of DMI on digestibility (Huhtanen et al., 2009). Reduced digestibility will usually reduce feed efficiency.

\section{Adaptation to the Diets}

A weakness of Latin square experiments is that short periods may not allow cows to fully adapt to the diets and the observed treatment differences might not

Table 8. Effect of diet and days on treatment on concentrations of acute phase protein in blood serum ${ }^{1}$

\begin{tabular}{|c|c|c|c|c|c|}
\hline \multirow[b]{2}{*}{ Item } & \multicolumn{4}{|c|}{ Dietary treatment ${ }^{2}$} & \multirow[b]{2}{*}{$\mathrm{SE}$} \\
\hline & 25CMP-CR & $0 \mathrm{CMP}$ & 25CMP-FCR & 40CMP-FCR & \\
\hline \multicolumn{6}{|l|}{$\overline{\text { Day } 2^{3}}$} \\
\hline Amyloid A, $\mu \mathrm{g} / \mathrm{L}$ & 59 & 73 & 56 & 77 & 24 \\
\hline Haptoglobin, mg/L & 166 & 194 & 184 & 290 & 49 \\
\hline \multicolumn{6}{|l|}{ Day 28} \\
\hline Haptoglobin, mg/L & 170 & 210 & 174 & 242 & 49 \\
\hline
\end{tabular}




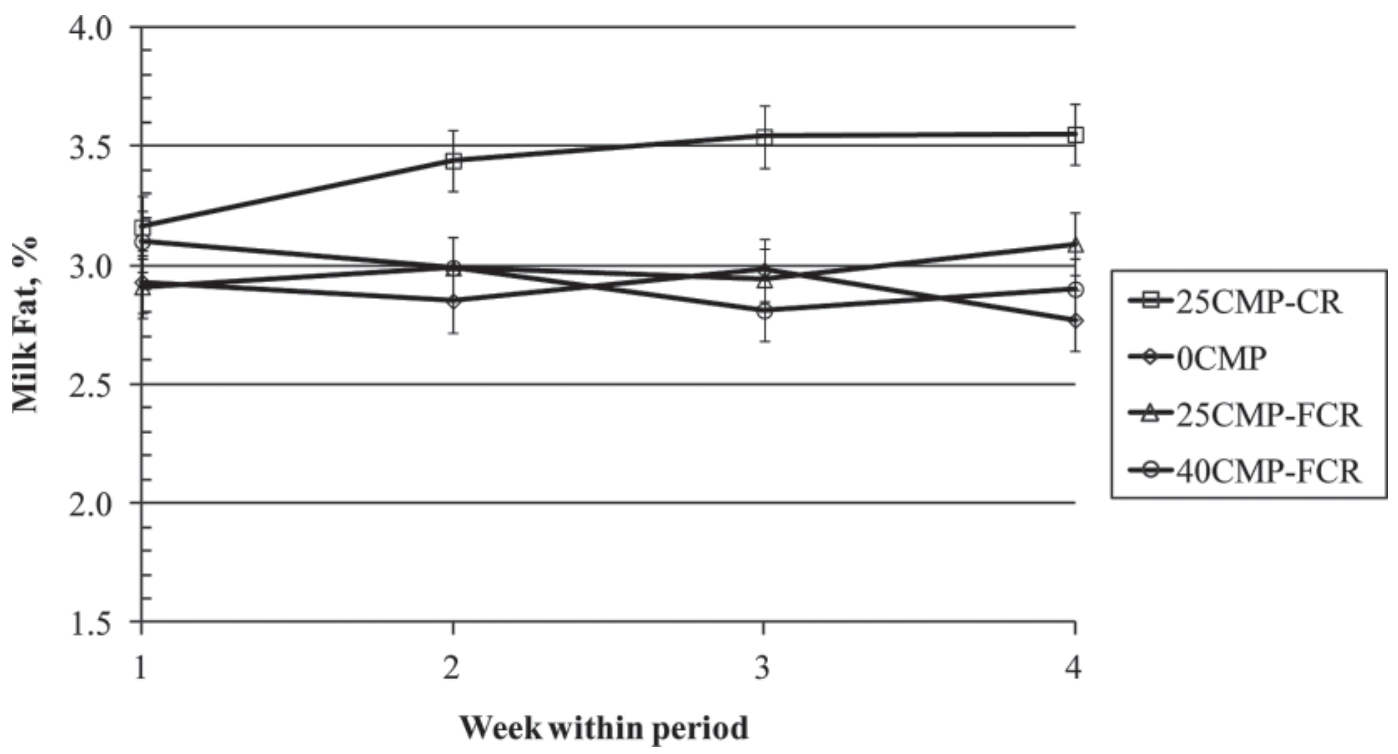

Figure 2. Change in milk fat concentration as cows adjusted to diets (weekly values are averaged over periods within each treatment). Milk sampling started $7 \mathrm{~d}$ after diets changed in each of the four 4 -wk periods. 0CMP, 25CMP-FCR, and 40CMP-FCR were diets with 0, 25, and $40 \%$ CMP that replaced forage and concentrate and 25CMP-CR contained 55\% forage (same as 0CMP) and 25\% CMP. All cows were fed the 0CMP diet for 1 wk before the first period.

reflect longer term results (Benefield et al., 2009). A separate statistical analysis that included week within period and week by treatment interaction was conducted. If the interaction was significant, treatment differences could be influenced by the length of the feeding period. The treatment by week interaction for milk, ECM, DMI, milk protein, and ECM/DMI was not significant $(P>0.4)$, but it was for milk fat percentage $(P<0.02)$ and milk fat yield $(P<0.05)$. Both variables had similar responses, so only milk fat percentage will be discussed. Milk fat percentage for cows fed the 25CMP-CR diet increased from wk 1 through 3 and then reached a plateau (Figure 2). Week 1 samples were taken $7 \mathrm{~d}$ after diets were changed. All cows were fed the 0CMP diet before the experiment so that all cows fed the 25CMP-CR in each period had been on a milk fat depressing diet $7 \mathrm{~d}$ before wk 1 samples were taken. Milk fat did not recover until at least $14 \mathrm{~d}$ after the diet change and appeared to continue to increase until $21 \mathrm{~d}$ after the diet change. Milk fat percentage was reasonably constant over the 4 -wk period for cows fed the milk fat depressing diets (0CMP, 25CMP-FCR, and 40CMP-FCR). For those 3 treatments, milk fat concentrations at wk 1 might be expected to be higher than in the other $3 \mathrm{wk}$ because of carryover from the preceding treatments. Carryover effects would have been diluted because, of the 48 cow-periods for the 3 milk fat depressing diets, only 12 (25\%) cow-periods were preceded by the $25 \mathrm{CMP}-\mathrm{CR}$ diet (i.e., the diet that resulted in normal milk fat). The other possibility is that milk fat decreased very rapidly after the diet change (much shorter period than needed for milk fat to recover to normal values). This analysis suggests that 4 -wk periods were adequate for this experiment (only the last 2 wk of production data were used) but shorter periods may have reduced the difference between the 3 milk fat depressing diets and the 25CMP-CR diet. Pereira et al. (1999) determined that 3 -wk periods were adequate for studies evaluating effective fiber but they did not examine shorter periods.

\section{CONCLUSIONS}

When CMP reduced dietary starch by replacing corn meal and soybean meal, milk fat increased and the calculated $\mathrm{NE}_{\mathrm{L}}$ concentration of the diet did not change, suggesting improved rumen fermentation and reduced negative associative effects. However, when CMP replaced forage, corn meal, and soybean meal, resulting in lower concentrations of fNDF and starch, milk fat concentration remained low and calculated dietary $\mathrm{NE}_{\mathrm{L}}$ was reduced. High ratios of starch to fNDF or of NFC to fNDF were associated with milk fat depression.

\section{ACKNOWLEDGMENTS}

Salary and research support was provided by state and federal funds appropriated to the Ohio Agricultur- 
al Research and Development Center, The Ohio State University, Manuscript 20-11AS. Additional financial support was provided by Cargill (Blair, NE).

\section{REFERENCES}

Allen, D. M., and R. J. Grant. 2000. Interactions between forage and wet corn gluten feed as sources of fiber in diets for lactating dairy cows. J. Dairy Sci. 83:322-331.

Allen, M. S. 2000. Effects of diet on short-term regulation of feed intake by lactating dairy cows. J. Dairy Sci. 83:1598-1624.

Allen, M. S., B. J. Bradford, and M. Oba. 2009. Board-invited review: The hepatic oxidation theory of the control of feed intake and its application to ruminants. J. Anim. Sci. 87:3317-3334.

AOAC. 2000. Official Methods of Analysis. Vol. 1 and 2, 17th ed. AOAC International, Gaithersburg, MD.

Beckman, J. L., and W. P. Weiss. 2005. Nutrient digestibility of diets with different fiber to starch ratios when fed to lactating dairy cows. J. Dairy Sci. 88:1015-1023.

Benefield, B. C., R. A. Patton, M. J. Stevenson, and T. R. Overton. 2009. Evaluation of rumen-protected methionine sources and period length on performance of lactating dairy cows within Latin squares. J. Dairy Sci. 92:4448-4455.

Boddugari, K., R. J. Grant, R. Stock, and M. Lewis. 2001. Maximal replacement of forage and concentrate with a new wet corn milling product for lactating dairy cows. J. Dairy Sci. 84:873-884.

Colman, E., W. B. Fokkink, M. Craninx, J. R. Newbold, B. D. Baets, and V. Fievez. 2010. Effect of induction of subacute ruminal acidosis on milk fat profile and rumen parameters. J. Dairy Sci. 93:4759-4773.

Dubois, M., K. A. Gilles, J. K. Hamilton, P. A. Rebers, and F. Smith. 1956. Colorimetric method for determination of sugars and related substances. Anal. Chem. 28:350-356.

Gencoglu, H., R. D. Shaver, W. Steinberg, J. Ensink, L. F. Ferraretto, S. J. Bertics, J. C. Lopes, and M. S. Akins. 2010. Effect of feeding a reduced-starch diet with or without amylase addition on lactation performance in dairy cows. J. Dairy Sci. 93:723-732.

Goering, H. K., and P. J. Van Soest. 1970. Forage fiber analysis. Agriculture handbook 379. USDA, Washington, DC.

Huhtanen, P., M. Rinne, and J. Nousiainen. 2009. A meta-analysis of feed digestion in dairy cows. 2 . The effects of feeding level and diet composition on digestibility. J. Dairy Sci. 92:5031-5042.

Jenkins, T. C. 2000. Feeding oleamide to lactating Jersey cows. 1. Effects on lactation performance and milk fatty acid composition. J. Dairy Sci. 83:332-337.

Jurjanz, S., O. Colin-Schoellen, J. N. Gardur, and F. Laurent. 1998. Alteration of milk fat by variation in the source and amount of starch in a total mixed diet fed to dairy cows. J. Dairy Sci. 81:2924-2933.
Khafipour, E., D. O. Krause, and J. C. Plaizier. 2009. A grain-based subacute ruminal acidosis challenge causes translocation of lipopolysaccharide and triggers inflammation. J. Dairy Sci. 92:10601070.

Knowlton, K. F., T. E. Dawson, B. P. Glenn, G. B. Huntington, and R. A. Erdman. 1998. Glucose metabolism and milk vield of cows infused abomasally or ruminally with starch. J. Dairy Sci. 81:3248-3258.

Mullins, C. R., K. N. Grigsby, D. E. Anderson, E. C. Titgemeyer, and B. J. Bradford. 2010. Effects of feeding increasing levels of wet corn gluten feed on production and ruminal fermentation in lactating dairy cows. J. Dairy Sci. 93:5329-5337.

NRC. 2001. Nutrient Requirements of Dairy Cattle. 7th rev. ed. Natl. Acad. Press, Washington, DC.

Nousiainen, J., M. Rinne, and P. Huhtanen. 2009. A meta-analysis of feed digestion in dairy cows. 1 . The effects of forage and concentrate factors on total diet digestibility. J. Dairy Sci. 92:5019-5030.

Pereira, M. N., E. F. Garrett, G. R. Oetzel, and L. E. Armentano 1999. Partial replacement of forage with nonforage fiber sources in lactating cow diets. I. Performance and health. J. Dairy Sci $82: 2716-2730$

Ranathunga, S. D., K. F. Kalscheur, A. R. Hippen, and D. J. Schingoethe. 2010. Replacement of starch from corn with nonforage fiber from distillers grains and soyhulls in diets of lactating dairy cows. J. Dairy Sci. 93:1086-1097.

SAS Institute. 2004. SAS/STAT User's Guide, Version 9. SAS Institute Inc., Cary, NC.

USDA. 2010. Feed grain data base: Yearbook tables. Econ. Res. Serv., USDA, Washington, DC. Accessed Aug. 17, 2011. www.ers.usda. gov/Data/FeedGrains/FeedYearbook.aspx\#FSI.

Voelker, J. A., and M. S. Allen. 2003. Pelleted beet pulp substituted for high-moisture corn: 1. Effects on feed intake chewing behavior, and milk production of lactating dairy cows. J. Dairy Sci $86: 3542-3552$

Weiss, W. P., N. R. St-Pierre, and L. B. Willett. 2009. Varying type of forage, concentration of metabolizable protein, and source of carbohydrate affects nutrient digestibility and production by dairy cows. J. Dairy Sci. 92:5595-5606.

Weiss, W. P., and D. J. Wyatt. 2000. Effect of oil content and kernel processing of corn silage on digestibility and milk production by dairy cows. J. Dairy Sci. 83:351-358.

Weiss, W. P., and D. J. Wyatt. 2003. Effect of dietary fat and vitamin E on alpha-tocopherol in milk from dairy cows. J. Dairy Sci 86:3582-3591.

Zebeli, Q., and B. N. Ametaj. 2009. Relationships between rumen lipopolysaccharide and mediators of inflammatory response with milk fat production and efficiency in dairy cows. J. Dairy Sci. 92:3800-3809. 